\title{
REVIEW
}

\section{IMMUNIZATION AGAINST DIPHTHERIA IN JAPAN}

\author{
RyosUKe MURATA
}

National Institute of Health, Kamiosaki, Shinagawa-ku, Tokyo 141

(Received August 25, 1981. Accepted September 25, 1981)

\section{CONTENTS}

1. Introduction

2. Schedule of immunization

3. Diphtheria toxoid

4. Program of surveillance on the immune status against diphtheria

5. Immune status of children

6. Epidemiological feature of diphtheria

7. Discussion

\section{INTRODUCTION}

Diphtheria was one of the commonest diseases among children in Japan before 1965. As the nation-wide immunization was not performed before 1946 , immunity against the disease was conferred exclusively by contact with toxigenic diphtheria bacilli. Campaign for mass immunization was opened by the government in 1946 to control the disease prevailing throughout the country at that time (Nobechi, 1946). The program of mass immunization was promoted actively by the enactment of the Preventive Vaccination Act (PVA) in 1948, which provided compulsory immunization against certain diseases including diphtheria (refer to Kanai, 1980). However, the immunization program was interrupted by the accident having occurred in December, 1948 in Kyoto after injection of a diphtheria toxoid (Kurokawa and Murata, 1961). Although the vaccination was reopened in 1950, no reliable statistics was available as to the actual status of immunization before 1952. Immunization against diphtheria was practised steadily since 1952 (Kurokawa, 1959), but the effectiveness was not so remarkable as expected before the combined vaccine was introduced for immunization of young children (see below). A large-scale survey of the immune status of children was first carried out in 1955 (Igarashi, 1956) and has been made every year since 1962. This paper reviews the change in the immune status of children against diphtheria and the incidence of the disease during these 30 years.

村田良介（国立予防衛生研究所） 


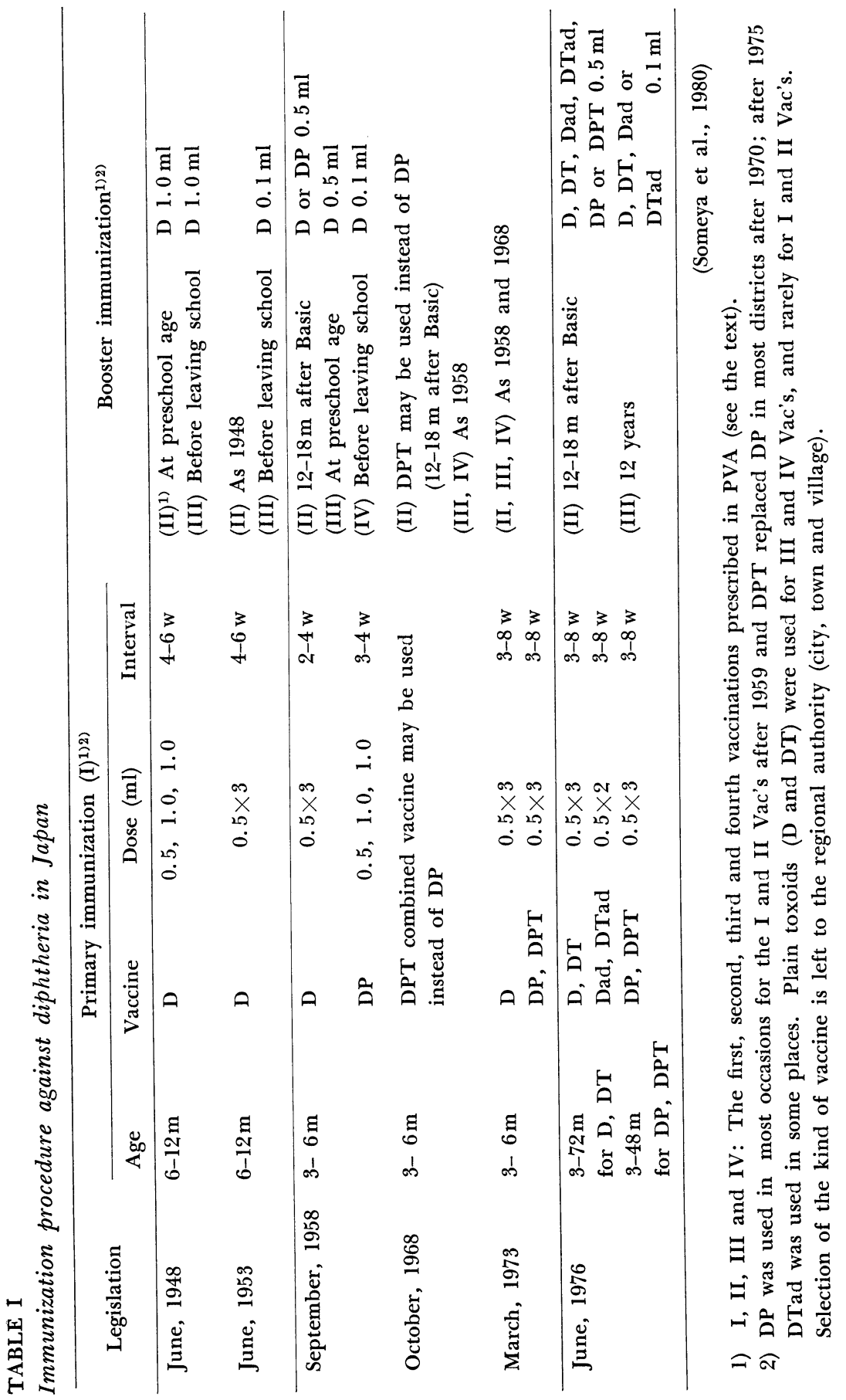


TABLE II

Some characteristics of diphtheria toxoid preparations

(1) Amount of diphtheria toxoid (Lf/ml)*

\begin{tabular}{|c|c|c|c|c|c|}
\hline Year & D & DT & DTad & DP & DPT \\
\hline 1958 & N.D. & & & $50-144$ & \\
\hline \multicolumn{6}{|c|}{$\begin{array}{l}\text { Prescribed in Min Req in March, 1959: not } \\
\text { more than } 70 \mathrm{Lf} / \mathrm{ml} \text { for plain toxoid }\end{array}$} \\
\hline $1959-1960$ & $50-72$ & & & $50-90^{* *}$ & $\left(\begin{array}{l}\text { Produced } \\
\text { since 1964 }\end{array}\right)$ \\
\hline $1961-1965$ & $50-64$ & $\left(\begin{array}{l}\text { Produced } \\
\text { since 1972 }\end{array}\right)$ & & $50-72$ & $56-64$ \\
\hline $1966-1972$ & $50-64$ & 70 & $\left(\begin{array}{l}\text { Produced } \\
\text { since 1973 }\end{array}\right)$ & $\begin{array}{c}42-77 \\
\text { (mostly }<65 \text { ) }\end{array}$ & $\begin{array}{c}43-73 \\
\text { (mostly }<65)\end{array}$ \\
\hline \multicolumn{6}{|c|}{$\begin{array}{l}\text { Min Req (revised) in 1973: not more than } \\
50 \mathrm{Lf} / \mathrm{ml} \text { for adsorbed toxoids }\end{array}$} \\
\hline $1973-1975$ & $56-70$ & $\begin{array}{c}56-80 \\
(\text { mostly }<65)\end{array}$ & $39-53$ & $\begin{array}{c}42-56 \\
\left(\begin{array}{l}\text { Not produced } \\
\text { since } 1975\end{array}\right)\end{array}$ & $\stackrel{40-72}{(\text { mostly }<60)}$ \\
\hline $1976-1980$ & $58-69$ & $\begin{array}{c}49-74 \\
\text { (mostly }<65)\end{array}$ & $\begin{array}{c}38-60 \\
\text { (mostly }<50)\end{array}$ & & $\begin{array}{c}33-69 \\
\text { (mostly }<60)\end{array}$ \\
\hline
\end{tabular}

* Figures show the results of titration at the NIH.

** Some products produced before April, 1959 contained 80-90 Lf/ml.

(2) Purity of the bulk toxoid (prescribed in 1971): no less than 1,500 Lf and 2,500 Lf per mg protein nitrogen, for the usual toxoids and for that for adult use, respectively.

(3) Aluminum content: (i) no higher than $10 \mathrm{mg}$ per $\mathrm{ml}$ as alum by Min Req of 1952; $2 \mathrm{mg} \mathrm{Al}$ per $\mathrm{ml}$ by that of $1959 ; 1 \mathrm{mg} \mathrm{Al}$ per $\mathrm{ml}$ by that of 1971 .

Most preparations available now contain $0.3-0.5 \mathrm{mg}$ Al per $\mathrm{ml}$.

(ii) for Adsorbed Toxoid for adult use (1971): no higher than $0.5 \mathrm{mg} \mathrm{Al}$ per ml.

(4) Test for the reversal of toxicity: see Addendum 1.

(5) Potency: see Addendum 1.

\section{SCHEdUle of ImMUNIZATION}

The program of immunization against diphtheria has changed several times, reflecting the epidemiological situation of the disease as well as the development of the vaccines. Table I shows the history of the procedures of the immunization in Japan. The program may be divided into three stages for convenience.

$1946-1958$

In 1946, when the nation-wide vaccination against diphtheria was first planned, three injections of fluid diphtheria toxoid or two injections of adsorbed one were recommended for the primary immunization of infants. The PVA issued in 1948 provided that children should be immunized three times before they leave the primary school as shown in Table I. The primary immunization 
consisting of three injections of fluid diphtheria toxoid was called "First Vaccination (I Vac)" and the booster injections at the preschool age and before leaving school were called "Second and Third Vaccinations (II Vac and III Vac)" in the chronological order. Only fluid toxoid was adopted by PVA of 1948, because local irritation caused by adsorbed toxoid seemed to hamper practice of the immunization program, though adsorbed toxoid was also used tentatively for several months after the promulgation of the regulation.

$1958-1976$

In 1958, a booster injection 12-18 months after the primary immunization was adopted in PVA, since the duration of immunity endowed by the fluid toxoid was rather short (Okada et al., 1958b; Kurokawa, 1959). Thereafter, this booster injection was called Second Vaccination and the Second and Third ones of 1948 Act were called Third and Fourth Vaccination, respectively. Combined vaccine (DP) was introduced in 1958 to immunize young children (for I and II Vac's). Triple vaccine (DPT) was adopted in 1968 and replaced actually DP vaccine after 1970 (refer to Table II).

\section{$1976-1981$}

Immunization with the combined vaccine (DPT and DP) was interrupted tentatively for several months in 1975, when there were two fatal cases among children having received DPT vaccine (Kanai, 1980). This resulted in decreased immunization rates against diphtheria in 1975 and 1976, although adsorbed diphtheria toxoid or diphtheria-tetanus combined toxoid was used in some places. In 1976, the age for the First and the Second Vaccinations was shifted and the booster injection at the preschool age (III Vac of 1958 Act) was abolished, as the age limit of II Vac was extended to 72 months after birth and as a potent immunity was maintained for many years after II Vac (Someya et al., 1981). The Fourth Vaccination of 1958 Act was then called Third Vaccination. Adsorbed toxid was adopted regularly in PVA in 1976 to give a potent primary immunity to the children with contraindication(s) against pertussis vaccine.

\section{Diphtheria ToxoID}

Toxoid preparations have been produced after War mostly by private manufacturers based on "Minimum Requirement" (abbreviated to Min Req) (Ministry of Health and Welfare, 1973) and subjected to the national control tests by the National Institute of Health (NIH) like other biological products (Kurokawa, 1975). The national control of the biological products started in 1947. Since then, all the products have been tested twice, i.e., at the manufacturer's laboratory and NIH. The requirements for diphtheria toxoid preparations were first issued in 1947 and have been revised several times on account of the development of the studies on the toxoid preparations (Someya, 1966, 1967, 1972; Someya 
TABLE III

Outline of surveillance

\begin{tabular}{ccc}
\hline Year & $\begin{array}{c}\text { Number of districts } \\
\text { involved }^{1)}\end{array}$ & Number examined \\
\hline 1955 & 529 & 31,681 \\
1962 & 28 & 11,753 \\
1963 & 120 & 25,296 \\
1964 & 120 & 19,329 \\
1966 & 10 & 5,209 \\
1967 & 10 & 4,558 \\
1968 & 10 & 4,592 \\
1969 & 8 & 3,701 \\
1970 & 7 & 3,942 \\
1971 & 7 & 3,878 \\
1972 & 5 & 2,749 \\
1973 & 6 & 2,831 \\
1974 & 4 & 2,154 \\
1975 & 15 & 2,870 \\
1976 & 14 & 2,866 \\
1977 & 15 & 3,055 \\
1978 & 16 & 2,686 \\
1979 & 16 & 2,764 \\
\hline
\end{tabular}

(Miyamura, 1976: Ministry of Health and Welfare, 1972-1979)

1) City, town and village: 4, 18 and 22 Prefectures were involved, in 1962, 1963 and 1964, respectively. After 1966, one district was selected from each prefecture.

et al., 1972, 1980). The study on the adsorbed toxoid was delayed, because the preparation was not used regularly until the recent revise (1976) of the Preventive Vaccination Act (Table I).

The following preparations of diphtheria toxoid are available at present: Diphtheria toxoid, plain (D), Diphtheria toxoid, adsorbed.(Dad), DiphtheriaTetanus Combined Toxoid, plain (DT) and adsorbed (DTad), DiphtheriaPertussis Combined Vaccine (DP), Diphtheria-Pertussis-Tetanus Combined Vaccine (DPT) and Diphtheria toxoid, adsorbed for adult use.

Some criteria for control of the products are shown in Table II. Test for the reversal of toxicity was introduced in 1970 (Akama et al., 1971) (see Addendum 1). With regard to the potency tests in the present Min Req, refer to the Addendum 1. The procedures of the potency tests of the toxoid preparations have undergone several changes and such changes are shown in Addendum 2.

\section{Program of Surveillance for the Immune Status against Diphtheria}

Immune status of Japanese children was first examined by Schick test and 


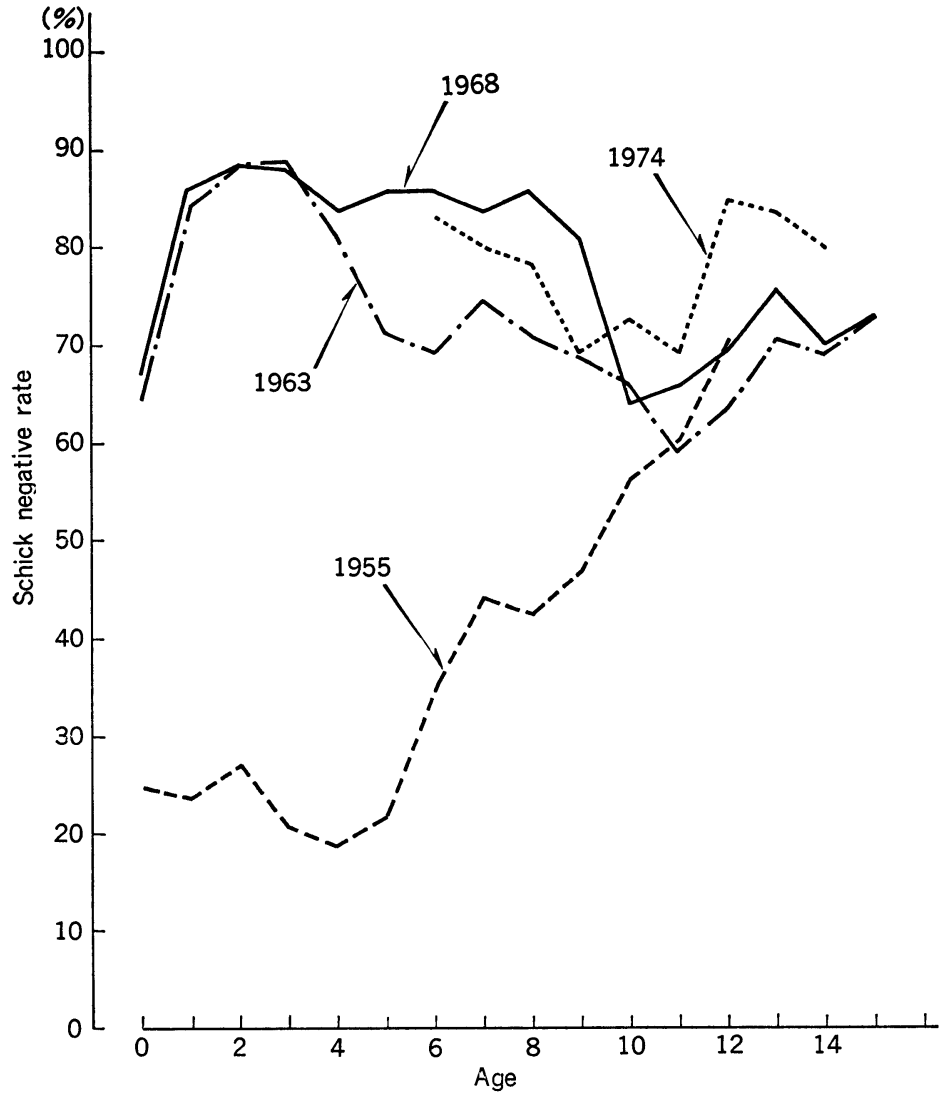

Fig. 1. Immune status of children examined by Schick test-age distribution.

Rates of Schick negative persons were plotted against the age in years. Figures attached to the curves show the calendar years of the surveillance (Quated from Igarashi, 1956 and Miyamura, 1976).

by titration of circulating diphtheria antitoxin since 1975 .

Schick test: Schick toxin was prepared by NIH. A test dose of the reagent contained $80 M R D$ by the rabbit ic test, $0.02 M L D$ (for guinea pigs) and 0.001 $\mathrm{L}+$ (Min Req, 1973). The result of the human skin test was judged $96 \mathrm{hr}$ after injection of $0.1 \mathrm{ml}$ of the reagent; the reaction of more than $10 \mathrm{~mm}$ in diameter was regarded as positive.

Titration of diphtheria antitoxin of human serum specimens: This was carried out by the micro cell culture method using VERO cells described by Miyamura et al. (1974a,b). The antitoxin titer was expressed in International Unit (IU).

Subjects of the survey: Surveillance after 1962 was carried out as a part of the National Forecasting Project of Communicable Diseases Outbreaks (refer to Kanai, 1980). Several prefectures covering different districts from north to south of Japan were involved. At least 200 children were tested from each of 
TABLE IV

Rate in percent of immunization against diphtheria

\begin{tabular}{|c|c|c|c|c|}
\hline \multirow{2}{*}{ Year } & \multirow{2}{*}{$\begin{array}{c}\text { Basic } \\
\text { immunization }\end{array}$} & \multicolumn{3}{|c|}{ Booster immunization at the age } \\
\hline & & $1-2 y$ & $6 y$ & $12 \mathrm{y}$ \\
\hline 1952 & 55 & & 55 & 61 \\
\hline 1953 & 54 & & 60 & 64 \\
\hline 1954 & 75 & & 73 & 74 \\
\hline 1955 & 61 & & 76 & 71 \\
\hline 1956 & 56 & & 68 & 70 \\
\hline 1957 & 55.4 & & 68.8 & 71.9 \\
\hline 1958 & 52.9 & & 70.7 & 64.1 \\
\hline 1959 & 53.1 & 29.2 & 67.3 & 52.1 \\
\hline 1960 & 51.8 & 51.7 & 63.9 & 59.3 \\
\hline 1961 & 46.5 & 53.4 & 59.9 & 61.1 \\
\hline 1962 & 51.4 & 56.8 & 56.0 & 57.9 \\
\hline 1963 & 51.3 & 63.1 & 57.0 & 52.1 \\
\hline 1964 & 48.4 & 51.6 & 55.0 & 58.0 \\
\hline 1965 & 48.9 & 54.0 & 58.8 & 62.3 \\
\hline 1966 & 48.0 & 48.9 & 53.6 & 56.6 \\
\hline 1967 & 45.2 & 47.8 & 55.8 & 60.8 \\
\hline 1968 & 50.5 & 46.7 & 55.3 & 61.3 \\
\hline 1969 & 47.7 & 44.2 & 56.2 & 56.4 \\
\hline 1970 & 40.0 & 40.2 & 50.3 & 50.3 \\
\hline 1971 & 41.1 & 40.2 & 53.0 & 57.2 \\
\hline 1972 & 48.4 & 38.6 & 65.4 & 59.6 \\
\hline 1973 & 52.1 & 49.4 & 53.6 & 60.6 \\
\hline 1974 & 58.9 & 55.0 & 60.4 & 59.1 \\
\hline 1975 & 16.2 & 26.6 & 58.0 & 68.4 \\
\hline 1976 & 12.5 & 34.8 & 23.5 & 33.7 \\
\hline 1977 & 39.7 & 26.0 & & 66.2 \\
\hline 1978 & 60.3 & 40.2 & & 79.3 \\
\hline 1979 & 61.2 & 61.1 & & 60.6 \\
\hline
\end{tabular}

(Ministry of Health and Welfare)

y: year

the following age groups: $0,1-2,3-5,6-9,10-14$, and more than 14 . Outline of the surveillance is shown in Table III.

\section{Immune Status of Children}

Table IV shows the actual state of immunization against diphtheria. Figure 1 shows the immune status of children in Japan. As seen in the figure, young children were poorly immunized in 1955 , although about $50 \%$ received 


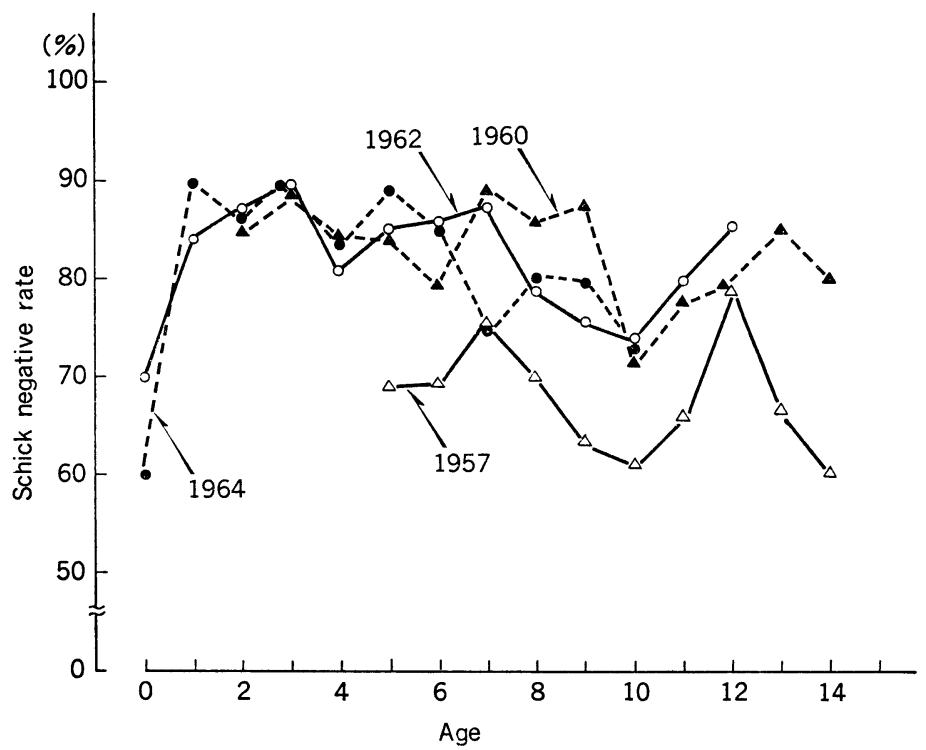

Fig. 2. Chronological change in immunity of children against diphtheria with reference to the year of birth

Rates of Schick negative persons were plotted against the age in years. Figures attached to the curves show the calendar years of birth (see the text). (Taken from Miyamura, 1976)

the primary immunization after 1952 (Table IV); three to five years old children showed the lowest immunity. This was explained by the improper procedure of immunization where plain toxoid was used and no booster injection was given before the age of six (Table I). In this respect, Okada et al. (1958b), Kurokawa (1959) and Kaneko (1962) pointed out that immunity conferred by plain toxoid decreased rapidly in 1-2 years. In some occasions only $20 \%$ of the vaccinees were Schick negative after 1 year, while the rate was higher than $70 \%$ when the combined vaccine was used for the primary immunization of the infants (Kaneko, 1962). In 1963, however, the immune status of children was improved remarkably by the change in the method of immunization; seventy percent of the children under five years showed Schick negative. Miyamura (1976) followed chronologically the change in the immunity of children born during the period of 1949-1969. The results of the surveillance carried out from 1955 to 1974 were combined and the change in the Schick-negative rate was figured with reference to the year of birth. She estimated that improvement of the immune status occurred between 1958 and 1960; children born after 1959 were endowed with such a potent immunity against diphtheria that lasted for several years. Figure 2 illustrates some examples from her study. The data were selected after consideration of the change in the immunization procedure (Table I). Although each curve was not always drawn from the data with the same children, the figure may be useful to estimate the tendency of the change 


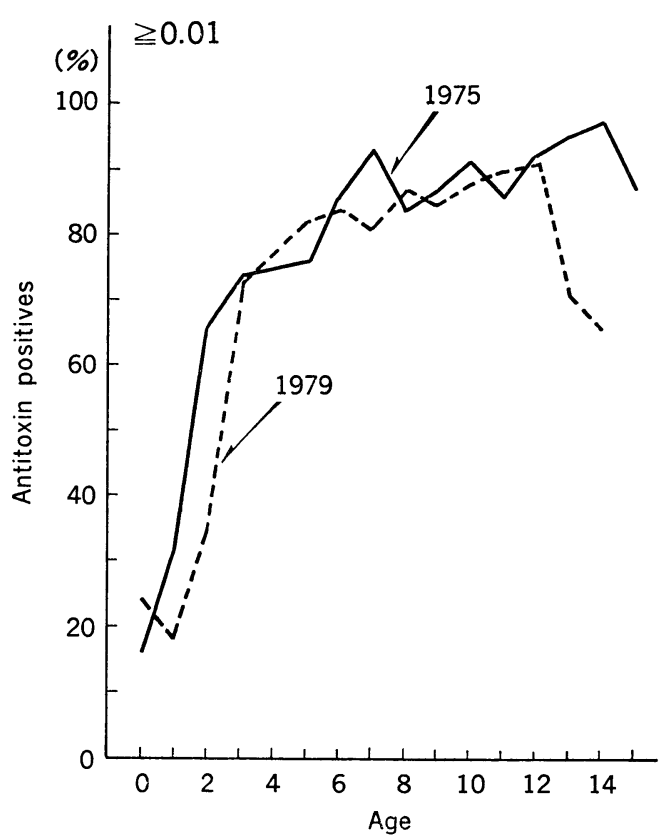

Fig. 3. Comparison of age distribution of diphtheria antitoxin by calendar year. Number of cases with antitoxin higher than $0.01 \mathrm{IU} / \mathrm{ml}$ were plotted against age (Ministry of Health and Welfare, 1972-1979).

in the immunity. Children born before 1957 showed the lowest immunity at every age and the value of Schick-negative rate at the age of 10 dropped below $70 \%$; the level is supposed to be necessary to maintain effective herd immunity. The level of immunity might have been much lower at the age of four when estimated from the reports stated above (Okada et al., 1958b; Kurokawa, 1959). On the other hand, the maintenance of immunity was much better among those born after 1959, corresponding to the revise of the immunization procedure in 1959 (Table I). The improvement of the immune status extended to the higher age groups year by year. Miyamura (1976) stated that the heightened immunity of children was entirely due to the injection of toxoid, but not to natural infection with diphtheria bacilli.

Figure 3 shows the immune status of children from titration of the circulating antitoxin after 1975. More than $70 \%$ of the children showed antitoxin titers exceeding $0.01 \mathrm{IU} / \mathrm{ml}$ at the age of three and such a high immunity persisted for at least 10 years. Immunization with combined vaccines (DPT and DP) was interrupted for several months after two accidental deaths occurring in 1974-1975, followed by vaccination with DPT (Kanai, 1980). Although diphtheria and diphtheria-tetanus combined toxoids (D, DT, Dad or DTad) were used in some places, the overall rate of immunization against diphtheria dropped sharply in 1975 and recovered gradually after 1978. Such change in 
TABLE V

Immune status of young adults ${ }^{1)}$

\begin{tabular}{|c|c|c|c|c|c|}
\hline \multirow{2}{*}{$\begin{array}{c}\text { Age } \\
\text { Year of birth }\end{array}$} & $15-17$ & $18-19$ & $20-21$ & $22-23$ & $24-25$ \\
\hline & 1963,1961 & $1960, \quad 1959$ & 1958,1957 & 1956,1955 & 1954,1953 \\
\hline \multirow{20}{*}{$\begin{array}{c}\text { Circulating1) } \\
\text { diphtheria } \\
\text { antitoxin }\end{array}$} & 0.64 & $\leqq 0.001$ & 0.03 & 0.056 & $\leqq 0.001$ \\
\hline & 0.01 & $\leqq 0.001$ & 0.02 & $\leqq 0.001$ & $\leqq 0.001$ \\
\hline & 1.30 & 0.08 & 0.16 & $\leqq 0.001$ & $\leqq 0.001$ \\
\hline & 0.64 & 0.04 & 0.003 & 0.08 & $\leqq 0.001$ \\
\hline & 0.08 & 0.04 & 0.01 & 0.005 & 0.01 \\
\hline & 0.32 & $\leqq 0.001$ & 0.08 & 0.005 & 0.01 \\
\hline & 0.46 & $\leqq 0.001$ & 0.46 & 0.32 & 0.16 \\
\hline & 0.90 & $\leqq 0.001$ & 0.05 & $\leqq 0.001$ & 0.02 \\
\hline & 0.64 & 0.02 & 0.003 & 0.32 & 0.08 \\
\hline & 1.80 & 0.64 & 0.003 & 0.005 & 0.01 \\
\hline & 0.08 & 0.90 & 0.01 & 0.005 & $\leqq 0.001$ \\
\hline & 1.80 & 0.16 & 0.003 & 0.01 & $\leqq 0.001$ \\
\hline & 1.80 & 0.02 & 0.90 & 0.08 & $\leqq 0.001$ \\
\hline & 1.30 & 7.20 & 0.32 & 0.01 & $\leqq 0.001$ \\
\hline & 0.08 & 0.02 & 0.32 & 0.64 & $\leqq 0.001$ \\
\hline & 0.64 & 0.16 & 0.02 & 0.08 & $\leqq 0.001$ \\
\hline & 0.46 & 0.003 & 0.16 & 0.005 & 0.01 \\
\hline & 0.64 & 1.30 & 0.16 & $\leqq 0.001$ & $\leqq 0.001$ \\
\hline & 0.64 & 0.01 & 0.01 & 0.16 & 0.32 \\
\hline & 2.60 & 0.16 & 0.04 & 0.005 & 0.005 \\
\hline $\begin{array}{l}\text { Mean' }^{2} \\
\text { (f. 1) }\end{array}$ & $\begin{array}{c}0.49 \\
(0.26,0.92)\end{array}$ & $\begin{array}{c}0.031 \\
(0.009,0.10)\end{array}$ & $\begin{array}{c}0.036 \\
(0.015,0.087)\end{array}$ & $\begin{array}{c}0.015 \\
(0.006,0.041)\end{array}$ & $\begin{array}{c}0.004 \\
(0.002,0.010)\end{array}$ \\
\hline
\end{tabular}

Murase and Kondo (1978)

1) Date of bleeding: January 23-March 24, 1978 in Tokyo.

Figures show the titers of diphtheria antitoxin $(\mathrm{IU} / \mathrm{ml})$ determined by the micro cell culture method.

2) Geometric means and fiducial limits at $P=0.95$.

the rate of immunization was reflected in the immune status of young children: difference was distinct in the production of antitoxin in children under 2 years between 1975 and 1979. The change in the immunization procedure in 1976 Act, which abolished the booster injection at the age of six, influenced the immune status of children around 6-8 years old; rise in antitoxin titer shown after III Vac in 1975 was not observed after 1976. However, the level of immunity necessary to protect the disease was maintained without the booster at this age.

As stated above, those who were born before 1958 seemed to be immunized poorly. The circulating antitoxin of the young adults was examined in 1978, as shown in Tables V and VI (Murase and Kondo, unpublished data; Ministry of Health and Welfare, 1979). As expected, the immunity was significantly low in the groups born before 1958, though differed depending on the districts. 


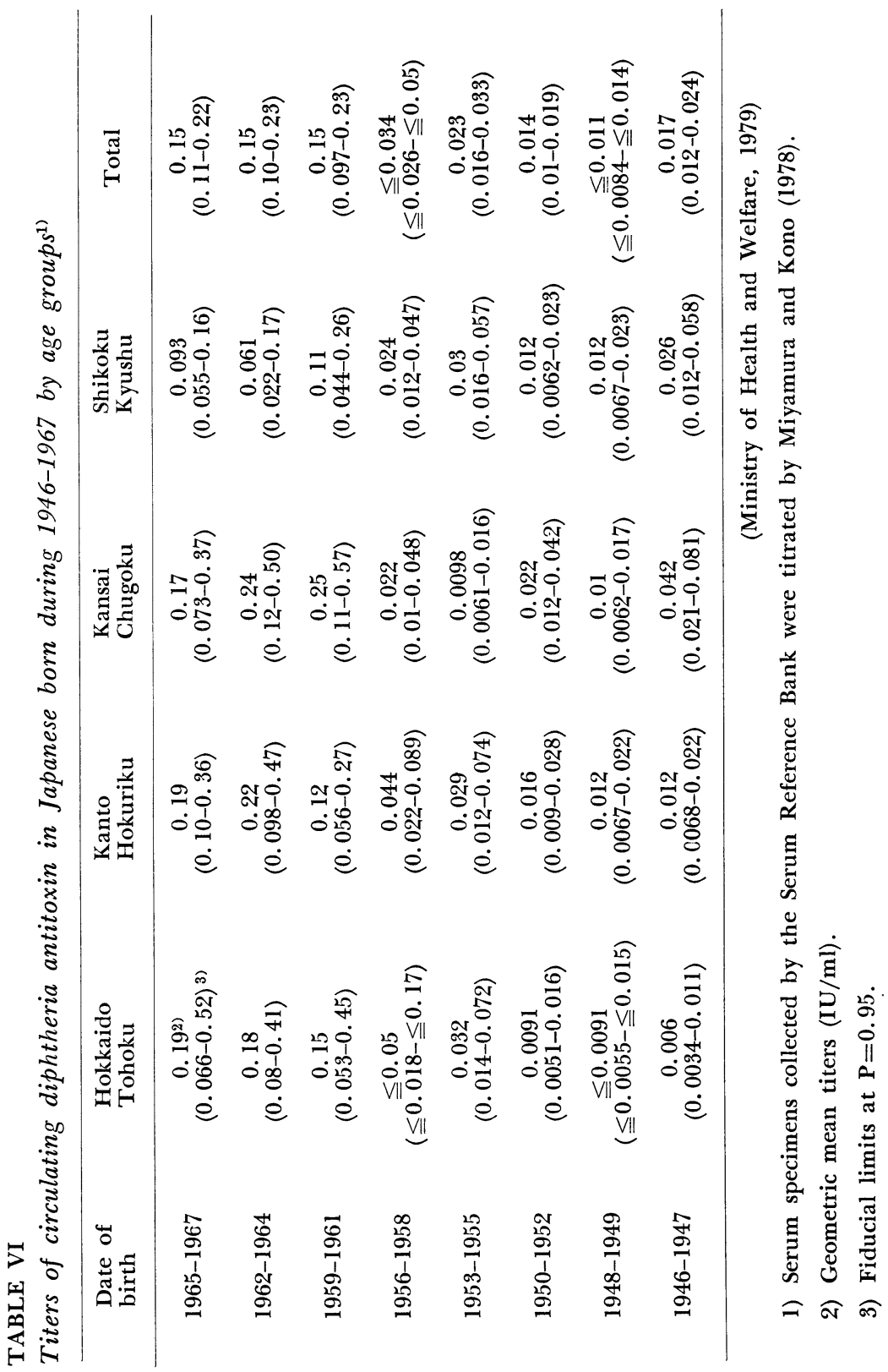




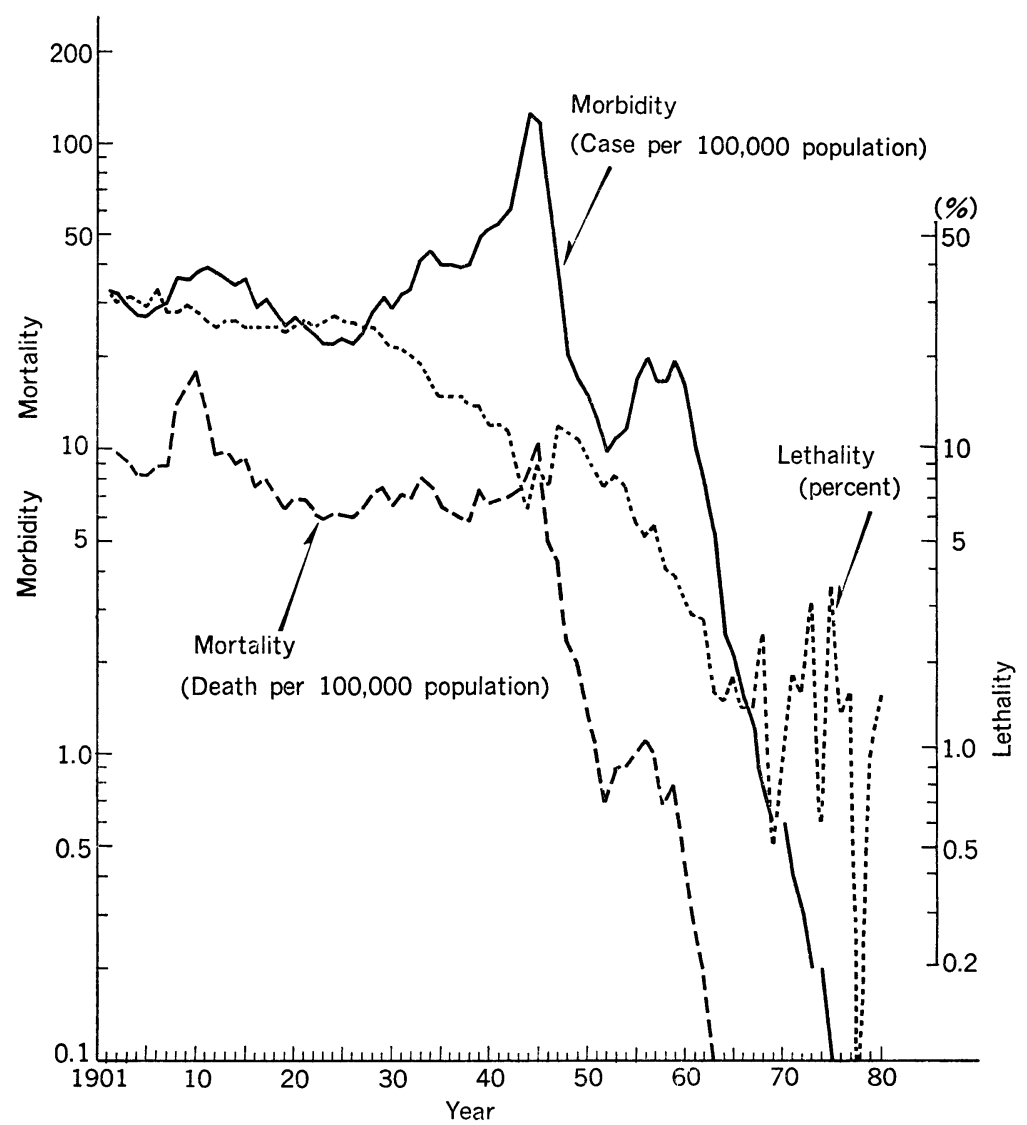

Fig. 4. Diphtheria in Japan (Vital Statistics by Ministry of Health and Welfare)

In this respect, Ashihara and Tokieda (1978) detected diphtheria antitoxin in only $10 \%$ among young adults of 27-29 years.

\section{Epidemiological Feature of Diphtheria}

Figure 4 shows the prevalence of diphtheria, a summary of notification from physicians; the cases were not always confirmed bacteriologically (see below). As will be seen, the disease prevailed during the year 1943-1945 and then the incidence dropped sharply, but increased again after 1953. The last epidemic (1955-1960) may have probably been due to the fact that the vaccination with fluid toxoid without booster injection was not so effective as to give a longlasting immunity (Fig. 1). Several reports are available concerning the epidemics (Okada et al., 1958a; Okada, 1960; Kurokawa et al., 1959; Fujimoto, 1958). Contrary to the previous epidemics, the peak of distribution shifted to the age 


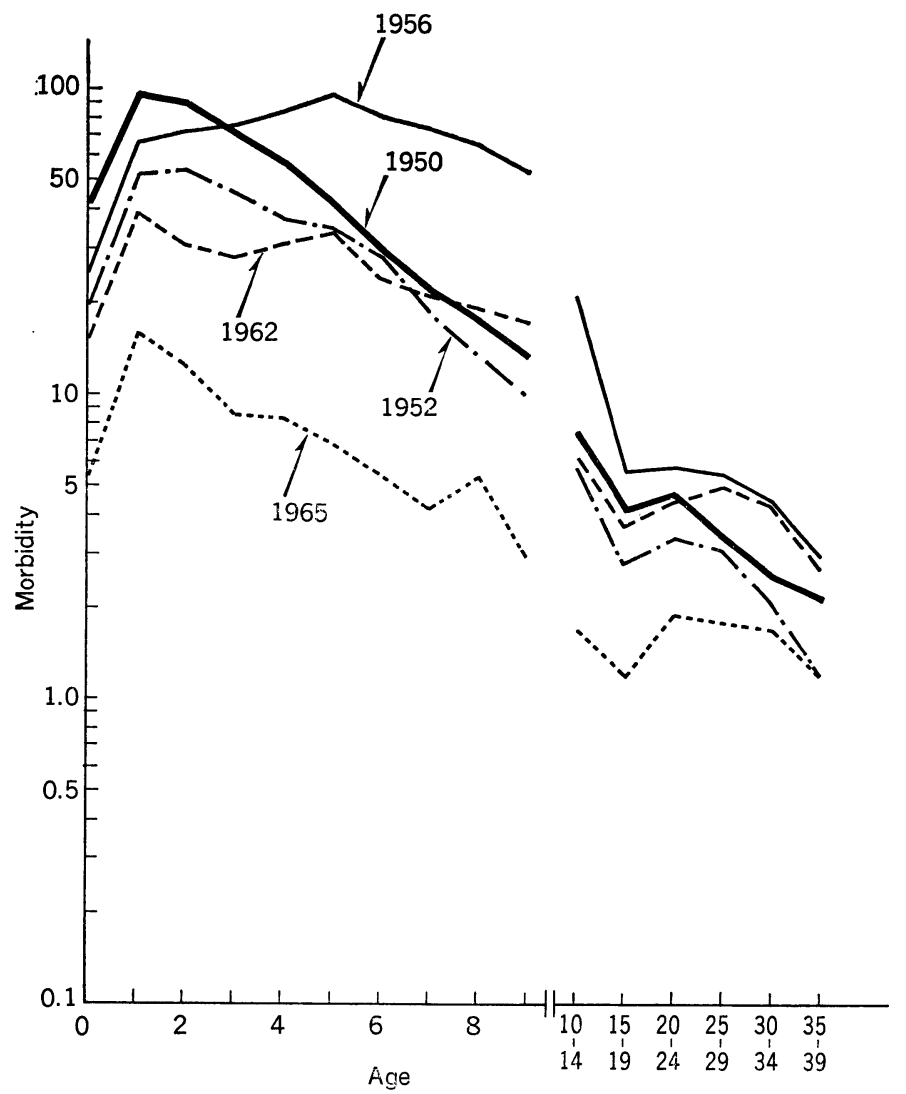

Fig. 5. Age distribution of diphtheria patients (Vital Statistics by Ministry of Health and Welfare).

groups of four to five during this epidemic (Fig. 5). The incidence reflected the low immunity of these groups (Fig. 1). The incidence of malignant cases was observed more often than the previous epidemics (Fujimoto, 1958) and gravis-type bacilli were prevalent (see below). However, the case fatality was not so high (Fujimoto, 1958). The incidence declined dramatically after 1960, when the combined vaccine was used generally and the immunization procedure was so changed as to give booster injection 12-18 months after the primary immunization. The situation was also coincided with the heightened immunity of children (Figs. 1 and 2). The pattern of age distribution changed again; the peak of the incidence shifted to the age groups of one (the curve of 1965 in Fig. 5). This change was in accordance to the improvement of the immune status among children at the age of two to three. The number of reported cases in 1980 was only 64 without death. Diphtheria has almost been eliminated in Japan.

Figure 6 shows the geographical distribution of the disease. Okada (1960) 


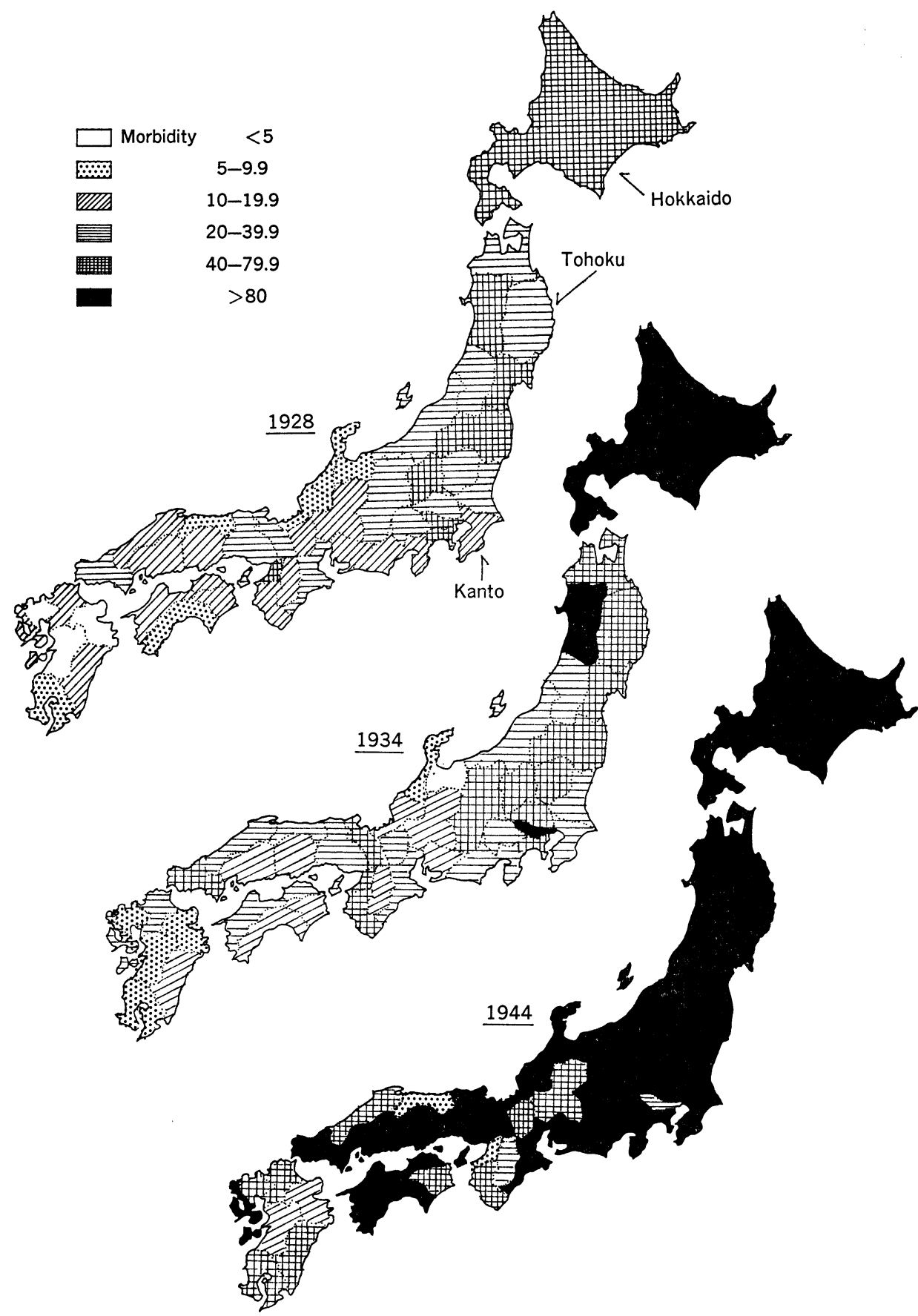

Fig. 6. Geographical distribution of diphtheria patients (Vital Statistics by Minitsry of Health and Welfare). 


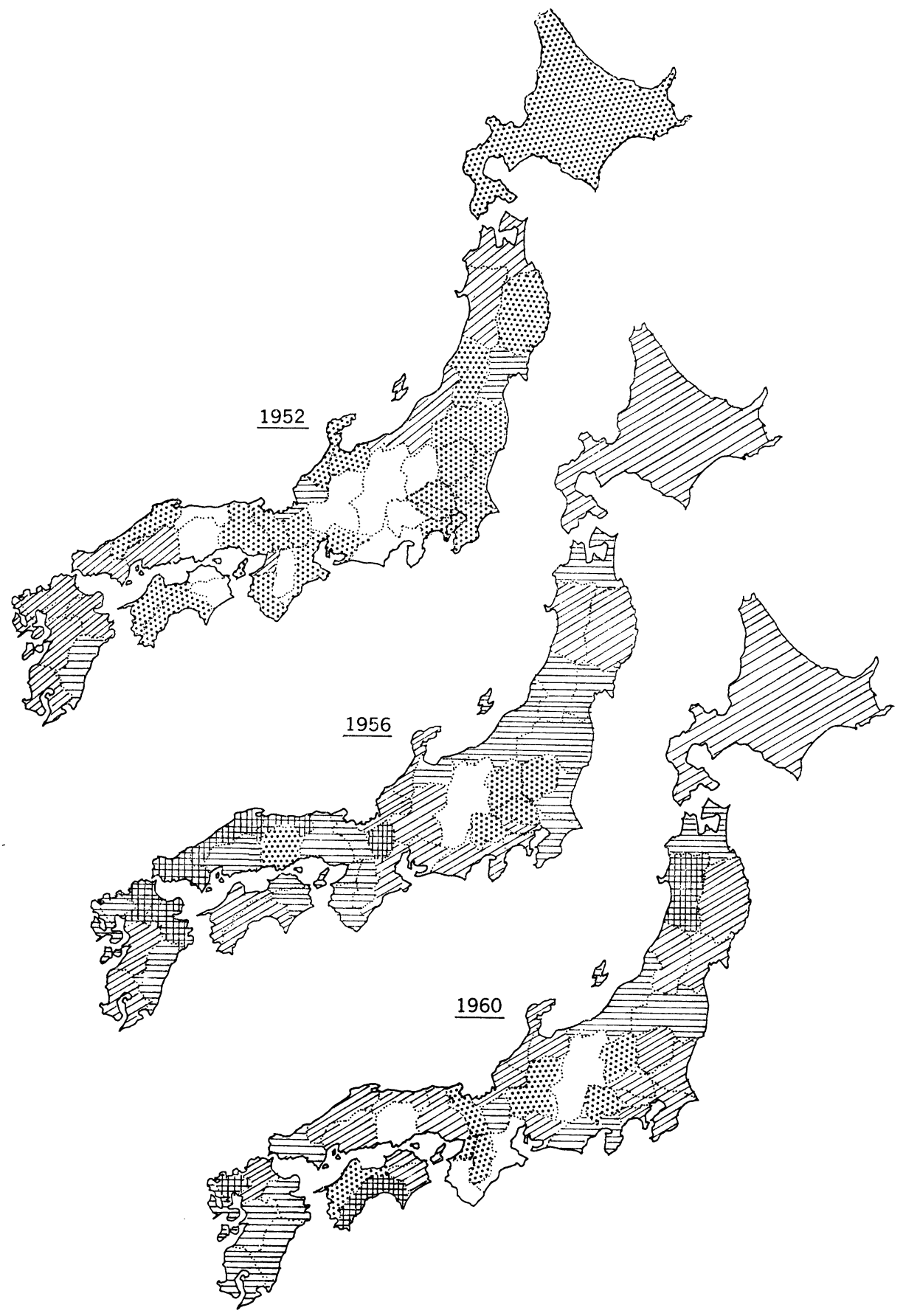




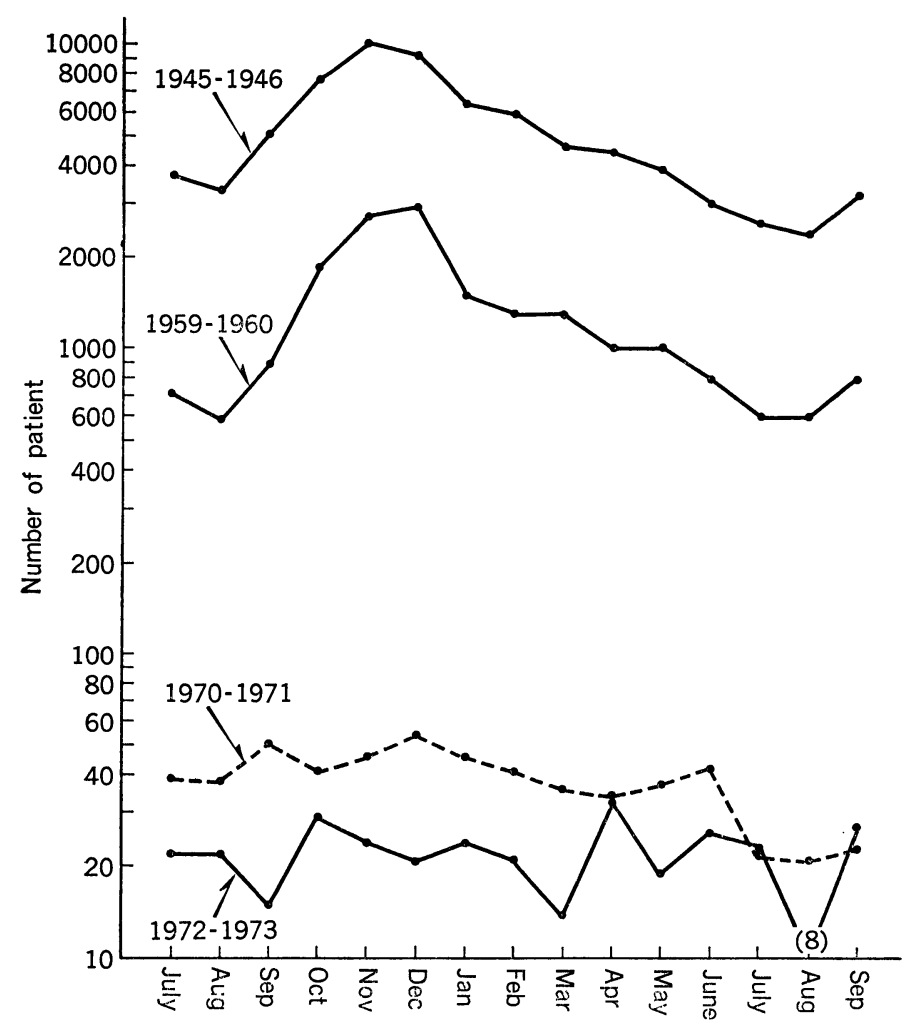

Fig. 7. Seasonal distribution of diphtheria patients (Vital Statistics by Ministry of Health and Welfare).

pointed out that the disease prevailed mostly in the northern parts of Japan especially in Hokkaido around the year of 1930 and extended to the south down to Kanto district in 1940 and finally spread throughout all districts of the country in the epidemic during 1943-1946.

Figure 7 shows the seasonal distribution of the disease. A distinct peak was observed in winter during the epidemics in 1943-1946 as well as in 19551960, while the seasonal variation became less distinct as the incidence declined.

The disease was confirmed bacteriologically during the epidemics before 1960 as shown in Table VII. It is of interest to refer to the change in the type of $C$. diphtheriae. Prior to 1950, mitis-type bacilli were relatively prevalent and non-toxigenic gravis-type bacilli were isolated often from the carriers (refer to Kurokawa et al., 1959), while the toxigenic gravis-type organisms were predominant in the most recent epidemic during 1955-1960 as shown in Table VII. Most strains of gravis-type bacilli were classified into four serological groups, 66, 155, K-23 and 8-14 (Fujimoto, 1958; Komachi, 1958; Kurokawa et al., 1959). Distribution of these groups was different depending on the districts. The former two groups were isolated in Osaka, while the latter two were predominant in 
the vicinity of Tokyo. These groups were not related to the serological types described by Robinson and Peeney (1936) (Fujimoto, 1959; Kurokawa et al., 1959).

Although the latest epidemic (1955-1960) was confirmed bacteriologically, isolation of the causative organisms from reported cases has been rare recently as pointed out by Mizuhara et al. (1966) and Akama (1975). These authors isolated Streptococci and other organisms from the lesion on the throat of the patients clinically diagnosed as diphtheria. Therefore, they threw doubt on the number of cases of diphtheria recently reported. Origuchi (1973) and Kobayashi et al. (1977) isolated diphtheria bacilli from patients and healthy persons. The latter authors reported a case of death due to severe diphtheria. The circulating antitoxin of the patient was below $0.001 \mathrm{IU} / \mathrm{ml}$. These facts show that diphtheria is still existent in Japan, though the number may be much smaller than those reported previously.

\section{Discussion}

Japanese children are immunized satisfactorily against diphtheria since the introduction of the combined vaccines (DP and DPT) in 1958. Primary immunization, followed by a booster injection given after 12-18 months, will give such immunity that may persist for 10 years. The booster immunization at the preschool age (III Vac of 1958 PVA) may not be necessary for those having history of complete immunization with the toxoid preparations with adjuvant (DP, DPT, Dad or DTad). Therefore, the Act was revised in 1976, when the age for I Vac was extended. In order to give a long-lasting potent immunity, plain toxoid should not be used for the primary immunization, although some physicians prefer it. For the children who may have the contraindication against pertussis vaccine, two injections of adsorbed toxoid (DTad or Dad), not a fluid toxoid, should be given. Adsorbed toxoid of no more than $50 \mathrm{IU} /$ dose may be enough for the primary immunization (Someya et al., 1981).

Young adults born during 1946-1958 seem to have been poorly immunized (Tables V and VI). This was due partly to the inadequate method of immunization with fluid diphtheria toxoid as stated above and partly to the decreased chances of natural infection (Fig. 4). The effect of the revised method of immunization with combined vaccine (DP) was inconsistent before the new method was used widely after 1960. Such situation as well as the low rate of immunization resulted in a large variation in the antitoxin titers among those born before 1960 (Table V). Although it may not be justifiable to compare the mean titers of such heterogeneous groups, the data in the tables may well show the trend of the change in the immune status of young adults in Japan. Further study is necessary on this point. The groups born in 1975-1977 may be also poorly immunized from the declined rate of immunization (Table IV). However, the number of children who receive injections personally from the home doctors has recently been increasing and is not always reported. Therefore, more children 
TABLE VII

Bacteriological examination of diphtheria

\begin{tabular}{|c|c|c|c|c|c|c|c|}
\hline \multirow{2}{*}{$\begin{array}{c}\text { Date } \\
\text { of } \\
\text { isolation }\end{array}$} & \multirow{2}{*}{ District } & \multirow{2}{*}{ Sourse } & \multirow{2}{*}{$\begin{array}{c}\text { Number } \\
\text { of } \\
\text { strain }\end{array}$} & \multicolumn{4}{|c|}{ Type of $C$. diphtheriae } \\
\hline & & & & Gravis & Intermedius & Mitis & Atypical \\
\hline 1954 & Yokosuka & Patient & 22 & 22 & 0 & 0 & 0 \\
\hline $1954-1955$ & Yokosuka & Carrier & 98 & 70 & 0 & 28 & 0 \\
\hline 1954-1956 & $\begin{array}{l}\text { Tokyo and } \\
\text { its vicinity1) }\end{array}$ & Patient & $62(8)^{3)}$ & $57(5)$ & 0 & $5(3)$ & 0 \\
\hline $1954-1956$ & $\begin{array}{l}\text { Tokyo and } \\
\text { its vicinity }\end{array}$ & Carrier & $144(49)^{3)}$ & 3) $87(12)$ & $10(2)$ & $39(30)$ & $8(5)$ \\
\hline$\rightarrow 1956$ & Tokyo & Patient & 50 & \multicolumn{4}{|c|}{ ND } \\
\hline Before 1957 & $\begin{array}{l}\text { Aichi, Mie and } \\
\text { Gifu }\end{array}$ & Patient & 41 & 31 & 6 & 4 & 0 \\
\hline Before 1957 & $\begin{array}{l}\text { Aichi, Mie and } \\
\text { Gifu }\end{array}$ & Carrier & 41 & 15 & 9 & 17 & 0 \\
\hline $1955-1957$ & Osaka & Patient & 504 & 364 & 5 & 72 & $63^{4)}$ \\
\hline $1955-1967$ & Vicinity of Osaka & Patient & 14 & 14 & 0 & 0 & 0 \\
\hline $1955-1967$ & Vicinity of Osaka & Carrier & 58 & 36 & 0 & 9 & $13^{5)}$ \\
\hline $1957-1958$ & Osaka & Carrier & 99 & $52(48)^{3)}$ & 0 & $47(43)$ & 0 \\
\hline 1958 & & Carrier & 34 & 0 & 0 & $34(5)^{3)}$ & ) 0 \\
\hline $1959-1961$ & Nagasaki & Patient & 88 & 74 & 6 & 8 & \\
\hline $1959-1961$ & Nagasaki & Carrier & 93 & 11 & 41 & 33 & 8 \\
\hline $1957-1961$ & Tokyo & Patient & $>350$ & \multicolumn{4}{|c|}{ ND } \\
\hline 1961 & Toyama & $\begin{array}{l}\text { Patient and } \\
\text { Carrier }\end{array}$ & 62 & 52 & $9(7)^{3)}$ & $1(1)$ & 0 \\
\hline 1962 & Toyama & Carrier & 100 & 51 & 21 & 25 & 3 \\
\hline $1967-1971$ & & Patient & 2 & \multicolumn{4}{|c|}{ ND } \\
\hline 1977 & Chiba & $\begin{array}{l}\text { Patient and } \\
\text { Carrier }\end{array}$ & 2 & 0 & 2 & 0 & 0 \\
\hline
\end{tabular}

1) Tokyo, Kanagawa, Chiba, Ibaraki and Shizuoka.

2) Tokyo, Kanagawa and Shizuoka.

3) Figures in parenthesis show the number of non-toxigenic strains, others were toxigenic.

4) Gravis (?): 61 ; Intermedius (?): 2 .

than shown in Table IV may have actually been immunized in 1975-1977. The age groups with poor immunity should be carefully watched at the time of epidemic, if any would occur in future.

The latest epidemic during 1955-1960 has several characteristic features as stated above; change in the age of distribution to the older groups (Fig. 5), predominance of the gravis-type bacilli (Type VII) and appearance of malignant cases. Age distribution may be explained by the fact that children born during 1947-1958 were poorly immunized, as stated above. The gravis-type diphtheria bacilli may cause infections among the population with insufficient immunity. Although malignant cases apparently increased, the case fatality rate was not so high as compared with the previous epidemics (Fujimoto, 1958), due probably 


\begin{tabular}{|c|c|}
\hline Remarks $^{6)}$ & Reporter $^{8)}$ \\
\hline All tox & Matsuo et al., 1955 \\
\hline All tox & Mizuhara, 1960 \\
\hline $\begin{array}{l}\text { For toxigenicity: } \\
\text { legend 3) }\end{array}$ & Kurokawa et al., 1959 \\
\hline $\begin{array}{l}\text { For toxigenicity: } \\
\text { legend 3) }\end{array}$ & Kurokawa et al., 1959 \\
\hline & Ebira, 1956 \\
\hline$\left(\begin{array}{l}7 \mathrm{G}, 5 \mathrm{I} \text { and } 1 \mathrm{M} \\
\text { tox }^{7}\end{array}\right.$ & Okada et al., 1958a \\
\hline \multirow[t]{4}{*}{$7 \mathrm{G}$ tox $^{7)}$} & Okada et al., 1958a \\
\hline & Komachi, 1958 \\
\hline & Komachi, 1958 \\
\hline & Komachi, 1958 \\
\hline $\begin{array}{l}\text { For toxigenicity: } \\
\text { legend 3) }\end{array}$ & Omori, 1959 \\
\hline $\begin{array}{l}\text { For toxigenicity: } \\
\text { legend 3) }\end{array}$ & Omori, et al., 1959 \\
\hline$G:$ tox & Tamai et al., 1963 \\
\hline$G:$ tox & $\begin{array}{l}\text { Tamai et al., } 1963 \\
\text { Minamizawa, } 1963\end{array}$ \\
\hline $\begin{array}{l}\text { For toxigenicity: } \\
\text { legend 3) }\end{array}$ & Ito et al., 1963 \\
\hline \multirow[t]{2}{*}{$\begin{array}{l}\left.28 \mathrm{G}, 21 \mathrm{I}, 19 \mathrm{M}: \operatorname{tox}^{7}\right) \\
4 \mathrm{G}, 4 \mathrm{M}: \text { atox }\end{array}$} & Kamegai et al., 1963 \\
\hline & Origuchi, 1973 \\
\hline tox & Kobayashi et al., 1977 \\
\hline
\end{tabular}

5) Gravis (?): 13 .

6) G: gravis, $I$ : intermedius, $M$ : mitis, tox: toxigenic, atox: non-toxigenic.

7) Not all strains were tested for toxigenicity.

8) For the reports before 1955, refer to Kurokawa (1959) and Kurokawa et al. (1959).

to the use of antibiotics and partly to the existance of the basic immunity though it might be imperfect. As regards the prevalence of the gravis type among the partially immune population, the infectivity and/or ability to produce toxin may be considered. Mueller (1941) stated that the gravis-type bacilli may be more suited to cause infection because they produce toxin in the presence of high iron contents as in the human tissue. However, Akama, Kameyama and Ito (1961) showed that the infectivity of diphtheria bacilli at the mucous membrane may not be directly related to the speed of in vitro growth nor to the ability to produce toxin under excess iron. Probably, some particular structure(s) may be important to stick to the living mucous membrane, e.g., such as reported by Yanagawa and his collegues (Yanagawa and Otsuki, 1970; Honda 
and Yanagawa, 1975, 1978).

Diphtheria still exists in Japan, although the incidence may not be so high as reported by the physicians and it will be a latent danger to those who are not immunized as shown by the report of Kobayashi et al. (1977). A nationwide bacteriological surveillance is necessary to catch the true picture of the disease.

\section{Acknowledgement}

The author wishes to thank Dr. R. Kono and Dr. K. Miyamura, Central Virus Diagnostic Laboratory, NIH, for providing the sero-epidemiological data and for their useful advice in preparing the manuscript. He is grateful also to Mr. Koichi Fujiwara of the Bureau of Public Health, Ministry of Health and Welfare, for his cooperation in collecting useful materials. He also appreciates greatly the cooperation of Dr. T. Murase, Director of Shibuya Medical Association, Tokyo and Dr. S. Kondo of the Second Department of Bacteriology of NIH in the seroepidemiological study.

\section{REFERENCES}

Akama, K. (1975): Some topics on diphtheria. Para-medical Information, 4, 3-8 (in Japanese).

Aкama, K., Kameyama, S. And Ito, A. (1961): On the difference between the toxigenicity and infectivity of $C$. diphtheriae. Japan. J. Med. Sci. Biol., 14, 263-267.

Akama, K., Kameyama, S., Otani, S., Sadahiro, S. and Murata, R. (1971): Reversion of toxicity of diphtheria toxoid. Japan. J. Med. Sci. Biol., 24, 183-187.

Ashinara, Y. and Tokifda, S. (1978): Studies on the immune status against diphtheria and preventive vaccination. Rinsho-to-Virus, Supplement, 43-50 (in Japanese).

Ebira, Y. ANd Kuniu, S. (1957): On the diphtheria bacilli isolated recently. Modern Media, 3, 56-58 (in Japanese).

Fujıмото, I. (1958): Epidemiology of gravis type diphtheria. Japan. J. Publ. Hlth, 22, 289-297 (text in Japanese).

Honda, E. And Yanagawa, R. (1975): Attachment of Corynebacterium renale to tissue culture cells by the pili. Amer. J. Vet. Res., 36, 1663-1666.

Honda, E. ANd Yanagawa, R. (1978): Pili-mediated attachment of Corynebacterium renale to mucous membrane of urinary bladder of mice. Amer. J. Vet. Res., 39, 155-158.

IgARASHI, Y. (1956): Incidence of diphtheria and epidemiological surveillance of the immune status. Japan. J. Publ. Hlth, 3, 42-44 (text in Japanese).

Ito, S., Kishioka, T., Takagi, K., Nishibe, Y., Nishida, Y., Hori, D., Kuramoto, Y. and Shirakata, T. (1963): A diphtheria epidemic of gravis type in Toyama Prefecture, I. Japan. J. Publ. Hlth, 10, 337-341 (text in Japanese).

Kamegai, T., Ito, S., Kishioka, T., Takagi, K., Nishibe, Y., Nishida, Y., Hori, D., Kuramoto, Y., Shirakata, T., Kaneko, Y. And Moriwaki, F. (1963): A diphtheria epidemic of gravis type, II. Japan. J. Publ. Hlth, 10, 1-9 (text in Japanese).

KANAI, K. (1980): Japan's experience in pertussis epidemiology and vaccination in the past thirty years. Japan. J. Med. Sci. Biol., 33, 107-143.

Kaneko, Y. (1962): Prevention of diphtheria. J. Japan Med. Assoc., 48, 1031-1038 (in Japanese).

Kobayashi, A., Sugano, H., Kikuchi, N., Watanabe, N. And Fujita, Y. (1977): A case of death due to diphtheria of adult. Nippon-Iji-Shinpo, No. 2799, 43-46 (in Japanese).

Комасні, Y. (1958): Transition of types of $C$. diphtheriae during epidemic in Osaka. Med. J. Osaka Univ., 10, 1125-1139 (in Japanese).

Kondo, S., Kameyama, S. and Murata, R. (1974): Standardization and control of toxoid components in the combined vaccine (DPT). Japan. J. Med. Sci. Biol., 27, 315-319.

Kurokawa, M. (1959): La vaccination antidiphterique et l'etat actuel de l'epidemie diphterique au Japon. Rev. d'Immunol., 23, 168-180.

Kurokawa, M. (1975): Production and control of the vaccine. p. 17-37. In H. Fukumi [ed.]. 
The Vaccination, Theory and Practice. International Medical Foundation, Tokyo.

Kurokawa, M., Nakano, T., Kondo, H., Yamanouchi, K., Kondo, S., Hirose, S. and Okazaki, S. (1959): Some observations on the strains of Corynebacterium diphtheriae isolated recently in Japan. Japan. J. Med. Sci. Biol., 12, 25-38.

Kurokawa, M. and Murata, R. (1961): On the toxicity of the "toxoid" preparation responsible for the Kyoto catastroph in 1948. Japan. J. Med. Sci. Biol., 14, 249-256.

Matsuo, T., Mizuhara, H., Yashiro, K., Inoue, Y. And Nozaki, K. (1955): Erythromycin therapy of diphtheria of children. Shonika-Shinryo, $18,782-787$ (in Japanese).

Minamisawa, Y. (1963): Recent cases of diphtheria from the point of clinical view. Modern Media, 9, 406-411 (in Japanese).

Ministry of Health and Welfare (1973): Minimum Requirement of Biological Products. p. 2849. Japanese Government, Tokyo.

Ministry of Health and Welfare (1972-1979): Report of the national forecasting project of communicable diseases outbreaks, 1972, 1973, 1974, 1975, 1976, 1977, 1978 and 1979.

MryamuRA, K. (1976): Diphtheria-"Report of the national forecasting project of communicable disease outbreaks". Rinsho-to-Saikin, 3, 157-163 (in Japanese).

Miyamura, K., Nishio, S., Ito, A., Murata, R. And Kono, R. (1974a): Micro cell culture method for determination of diphtheria toxin and antitoxin titers using VERO cells. I. Studies on factors affecting the toxin and antitoxin titration. J. Biol. Standard., 2, 189-201.

Miyamura, K., TaJiri, E., Ito, A., Murata, R. and Kono, R. (1974b): Micro cell culture method for determination of diphtheria toxin and antitoxin titers using VERO cells. II. Comparison with the rabbit skin method and practical application for sero-epidemiological studies. J. Biol. Standard., 2, 203-209.

Mizuhara, H. (1960): Some problems on the carrier of diphtheria bacilli and the therapy of them. Shonika, 1, 485-493 (in Japanese).

Mizuhara, H., Yasaka, A., Kageyama, K. and Kimura, H. (1966): Actual state of the children sent to hospital under the diagnosis of diphtheria. Shonika-Sinryo, 29, 85-87 (in Japanese).

Mueller, J. H. (1941): Toxin production as related to the clinical severity of diphtheria. J. Immunol., 42, 353-360.

Noвесні, K. (1946): Epidemiological observation of carrier of diphtheria bacilli. The Clinic. J. Japan, 4, 554-561 (in Japanese).

OKADA, H. (1960): Epidemiological consideration of diphtheria in recent years. Japan. J. Infect. Dis., 34, 789-801 (text in Japanese).

Okada, H., Sunaga, H., Ohnishi, T., Sakamoto, I., Mizuno, K., Takase, T., Kosugi, N. ANd Sakawa, S. (1958a): Recent epidemic of diphtheria (1) Type, toxigenicity and drug resistance of the prevalent organisms. Japan. J. Publ. Hlth, 5, 56-59 (text in Japanese).

Okada, H., Sunaga, H., Iwai, J., Ohnishi, T., Kubota, J., Yamaguchi, I., Yamamoto, N., Miyazaki, S., Ogiso, S. and Kano, S. (1958b): Recent epidemic of diphtheria (3) Effectiveness of the immunization and some consideration on the method of injection. Japan. J. Publ. Hlth, 5, 530-534 (text in Japanese).

Omort, G. (1959): Diphtheria due to mitis bacilli prevailed in a class of a primary school. Seikatsu-Eisei, 3, 67-73 (in Japanese).

Omori, G., Iwao, M., Yoshimura, A., Kishi, T., Kawagoe, K., Iso, N., Nishi, H., Susuki, S., Yamamoto, K., Sakaguchi, H. And FuJII, H. (1959): A survey of $C$. diphtheriae from healthy children in Osaka City. J. Osaka City Med. Coll., 8, 1-9 (text in Japanese).

Origuchi, T. (1973): Six cases of pharyngeal diphtheria of adult. Bull. Japan. Soc. Oto-rinolarynogol., 76, 1489 (text in Japanese).

Robinson, D. T. And Peeney, A. L. P. (1936): The serological types amongst gravis strains of C. diphteriae and their distribution. J. Pathol. Bacteriol., 43, 403-418.

Someya, S. (1966): Studies on the prophylactic effect and untoward reactions of pertussisdiphtheria combined vaccine. IV. Comparative investigation on the antibody productivity and temperature increase in infants inoculated with the combined vaccines (PD, PDT) and tetanus toxoid. Bull. Inst. Publ. Hlth, 15, 57-62 (text in Japanese).

Someya, S. (1967): Studies on the prophylactic effect and untoward reactions of pertussisdiphtheria combined vaccine. V. Relationship between the results from field trials and laboratory tests. Bull. Inst. Publ. Hlth, 16, 23-32 (text in Japanese).

Someya, S. (1972): Studies on the prophylactic effect and untoward reactions of of pertussisdiphtheria combined vaccine. VI. Report of field trial, 1966-1967. Bull. Inst. Publ. H1th, 
21, 68-76 (text in Japanese).

Someya, S., Murata, R., Kurokawa, M., Sato, Y., Kaneko, J., Yamamoto, S., Kasuga, T., Nakamura, B., Asano, S., Kokubu, Y., Matsumura, T., Shoji, T., Murata, F., Hirayama, M., Koshi, S. ANd Mizuhara, H. (1972): Studies on the prophylactic effect and untoward reactions of pertussis-diphtheria-tetanus combined vaccine with special reference to the concentration of tetanus toxoid contained in the PDT combined vaccine. Bull. Inst. Publ. Hlth, $21,121-126$ (text in Japanese).

Someya, S., Mizuhara, H., Murata, R. And Kurokawa, M. (1980): Change in the procedures of immunization against pertussis, diphtheria and tetanus. Rinsho-to-Saikin, 6, 393-416 (in Japanese).

Someya, S., Mizuhara, H., Murata, R. And Kurokawa, M. (1981): Studies on the adequate composition of diphtheria and tetanus toxoids-with reference to the amounts of toxoids and aluminum adjuvant. Japan. J. Med. Sci. Biol., 34, 21-35.

Tamai, T., Ishikawa, T., Fukuta, C., Shirahama, H., Nishimura, S., Kaneko, Y., Moriwaki, F. and Akama, K. (1963): Epidemiological and bacteriological studies of diphtheria epidemic in a miner town, Oshima Machi, Nagasaki Prefecture. Japan. J. Publ. Hlth, 10, 1-5 (text in Japanese).

Yanagawa, R. ANd Otuki, K. (1970): Some properties of the pili of Corynebacterium renale. J. Bacteriol., 101, 1063-1069. 


\section{Addendum 1.}

Some test procedures for the preparations of diphtheria toxoid (D, Dad, DP and Dad for adult use)

A) Diphtheria Toxoid

\subsubsection{Detoxification test}

The test shall be conducted on the test sample and that kept standing at $37 \mathrm{C}$ for 20 days, respectively.

3.3.6.1. Test in guinea pigs

Each sample shall be injected subcutaneously at a dose of $5 \mathrm{ml}$ into at least four guinea pigs weighing $300-400 \mathrm{~g}$. The animals shall be observed for at least 30 days. No animal shall die due to intoxication, or show any of such specific symptoms of intoxication as necrosis, paralysis, decrease in body weight, or any other abnormal sign during the observation period.

\subsubsection{Test in rabbits}

Each sample and the Schick Test Toxin diluted 40-fold in $0.0167 \mathrm{M}$ phosphate buffered sodium chloride solution containing gelatin at 0.2 $\mathrm{w} / \mathrm{v} \%$ shall be injected intracutaneously at a dose of $0.1 \mathrm{ml}$ into at least two rabbits weighing about $2.5 \mathrm{~kg}$. The animals shall be observed for 2 days.

The site injected with the dilution of Schick Test Toxin shall show specific reaction due to toxin, and no site injected with each sample shall show specific reaction or any other abnormal reaction.

\subsubsection{Potency test}

The potency shall be determined in guinea pigs by the toxin challenge method or by the antitoxin titration method.

\subsubsection{Toxin challenge method}

\subsection{Materials}

The test sample, Standard Diphtheria Toxoid (hereafter referred to as "Standard") and an appropriate toxin solution shall be used. The test sample and the Standard shall be diluted in $0.0167 \mathrm{~m}$ phosphate buffered sodium chloride solution containing $0.02 \mathrm{w} / \mathrm{v} \%$ gelatin, and toxin in $0.0167 \mathrm{M}$ phosphate buffered sodium chloride solution containing 0.2 $\mathrm{w} / \mathrm{v} \%$ gelatin, respectively.

\subsection{Test procedures}

The test sample and the Standard shall be diluted serially at equal logarithmic intervals. Each dilution shall be injected subcutaneously at a dose of $2 \mathrm{ml}$ into at least 10 guinea pigs weighing $300-400 \mathrm{~g}$. The animals shall be challenged with approximately $50 \mathrm{LD}_{50}$ of toxin after 4-6 weeks of immunizing injection. The animals shall be observed for 7 days.

The toxin used for challenge shall be titrated by injecting with each 
of at least three serial dilutions into at least three guinea pigs weighing about $400 \mathrm{~g}$. The challenge toxin shall contain $25-100 \mathrm{LD}_{50}$ per inoculum.

3.3.7.1.3. Criterion for judgement

The potency of the test sample shall be no less than that of the Standard upon statistical comparison of the results.

\subsubsection{Antitoxin titration method}

Antitoxin content of the serum shall be titrated by the rabbit intracutaneous method, cell culture method, or passive hemagglutination method.

\subsection{Materials}

The test sample, the Standard, Standard Diphtheria Antitoxin and a toxin solution with a known binding capacity shall be used. When the passive hemagglutination method is used, red blood cells shall be sensitized with diphtheria toxin or toxoid of a purity no less than 2,500 $\mathrm{Lf} / \mathrm{mgN}$.

\subsection{Test procedures}

Immunizing injection of animals shall be conducted by the method given in 3.3.7.1.2.

Antitoxin content of the serum from each animal shall be determined after 4 to 6 weeks of immunization.

\subsection{Criterion for judgement}

The criterion given in 3.3.7.1.3. shall apply.

B) Adsorbed Diphtheria Toxoid

\subsubsection{Detoxification test}

The test given in 3.3.6. of Diphtheria Toxoid shall apply.

\subsubsection{Potency test}

The test given in 3.3.7. of Diphtheria Toxoid shall apply except that the Standard Diphtheria Toxoid in 3.3.7.1.1. shall read Standard Adsorbed Diphtheria Toxoid. The diluent of the test sample and the Standard shall be isotonic sodium chloride solution.

C) Diphtheria-Pertussis Combined Vaccine

3.3.10. Test for detoxification of diphtheria toxin

Requirements given in 3.3.6.2. of Diphtheria Toxoid shall apply, excluding the test on the sample kept standing at $37 \mathrm{C}$ for 20 days in the case of final product.

\subsubsection{Potency test}

Requirements given in 3.3.10. of Pertussis Vaccine and 3.3.7. of Diphtheria Toxoid shall apply with modification of the specification "Standard Diphtheria Toxoid" in 3.3.7. of Diphtheria Toxoid to "Reference Diphtheria Toxoid (for Combined Vaccine)."

D) Adsorbed Toxoid for Adult Use

3.3. Control tests on final product

The test given in 3.3. of Adsorbed Diphtheria Toxoid shall apply except that the test given in 3.3.8. shall be conducted in the following 
way:

The test sample shall be injected subcutaneously at a dose of $0.5 \mathrm{ml}$ into at least 10 guinea pigs weighing $300-400 \mathrm{~g}$. The animals shall be bled after 4-6 weeks of immunizing injection, and the antitoxin titer of each serum shall be titrated by intracutaneous injection into rabbits.

The geometric mean of the values shall be no less than 0.1 unit per $\mathrm{ml}$.

Notes: The above-mentioned methods are the transcripts from the Minimum Requirement of Biological Products (Ministry of Health and Welfare, 1973). Heading figures show those appeared in the respective individual "Requirement" of the Document. Detoxification test is carried out on bulk material and final product.

\section{Addendum 2.}

History of the change of the potency tests

Potency test of plain toxoids ( $D$ and DT): (Min Req, 1947) “At least 10 guinea pigs shall receive one-fifth the volume of the total human immunizing dose and shall be challenged with 10 MLD of diphtheria toxin 4-6 weeks after the immunization. The product shall pass the test when eighty percent of the animals (not less than 10 animals) shall survive." The concept of the relative potency was introduced in 1959 and the first Standard Diphtheria Toxoid, plain (3 IU/ml), was established. Requirement for DT toxoid, plain was enacted in 1973.

Potency test of adsorbed toxoids (Dad and DTad): (Min Req, 1947) “A group of guinea pigs shall receive the adsorbed toxoid at a dose of not more than one half the volume of the total human immunizing dose. The product shall pass the test when circulating antitoxin of at least $2 \mathrm{IU} / \mathrm{ml}$ shall be produced in 4-6 weeks in an aliquot-pool from not less than four animals." Minimum Requirement for Diphtheria-Tetanus Combined Toxoid, adsorbed was enacted in 1973. The Standard Toxoid, adsorbed (74 IU / ml) was established in 1973 and the procedure for the potency test was revised.

Potency test of the combined vaccines (DP and DPT): (Min Req, 1958) The DP vaccine was tested by procedures similar to that for the plain toxoid, except that the immunizing dose was $0.25 \mathrm{ml}$. "The product shall pass the test when eighty percent of the animals (not less than 10) shall survive."

The concept of the relative potency was introduced in 1959. The products have since then been tested with Standard Diphtheria Toxoid, plain ( $3 \mathrm{IU} / \mathrm{ml}$ ) and the potency of the test specimen should be seven times as much as the Standard. Minimum Requirement for DPT vaccine was enacted in 1964. In 1975, Reference Diphtheria Toxoid (for combined vaccine) replaced the Standard stated above: A potency of 20 Protective Unit per $\mathrm{ml}(\mathrm{PU} / \mathrm{ml})$ was tentatively assigned to the Reference by comparison of the potency with that of the com- 
bined vaccine (DPT) titrated against the International Standard Diphtheria Toxoid, plain (refer to Kondo, Kameyama and Murata, 1974). 